\title{
Efek Kombinasi Back Massage dan Acupoint Massage terhadap Peningkatan Kadar Prolaktin
}

\section{The Effects of a Combination of Back Massage and Acupoint Massage on Increasing Prolactin Levels}

\author{
Wita Asmalinda ${ }^{1}$, Dian Lestari ${ }^{2}$ \\ Jurusan Kebidanan, Politeknik Kesehatan Kemenkes Palembang, Indonesia
}

\section{ARTICLE INFO}

\section{Article history}

Received date

27 August 2020

Revised date

29 August 2020

Accepted date

31 August 2020

\section{Keywords:}

Acupoint massage;

Backmassage;

Prolactin.

Kata kunci:

Acupoint massage;

Back massage;

Prolaktin.

\author{
ABSTRACT/ ABSTRAK
}

\begin{abstract}
Stimulation of the nipples can be done with acupoint massage at the acupressure points around the breast. Acupoint massage therapy can help maximize prolactin and oxytocin receptors and minimize the side effects of late breastfeeding by babies. Back Massage at the meridian point will activate the release of endorphins hormone which has an effect on the sense of comfort and relax in the mother so that an increase in milk production. The aims of this research to know the effects of a combination of back massage and acupoint massage on increasing prolactin levels. This type of research is experimental epidemiology with a comparison group (post-test only with control group design). This research was conducted at BPM Meli Rosita for 3 months. The sample in this study was postpartum women who met the inclusion and exclusion criteria. A sample size of 34 people. The measurement parameter had an increase in prolactin. Which included at homogeneity test sample using the Kolmogorov-smirnov test, description analysis to know to mean value, and standard deviation. There was a significant increase in the number of prolactin. The combination of back massage and Acupoint massage affects the increase prolactin level.
\end{abstract}

\begin{abstract}
Perangsangan puting susu dapat dilakukan dengan tindakan acupoint massage pada titiktitik akupresur di sekitar payudara. Terapi Acupoint massage dapat membantu memaksimalkan reseptor prolaktin dan oksitosin dan meminimalkan efek samping terlambat menyusui oleh bayi. Back Massage pada titik meridian akan mengaktivasi pengeluaran hormon endorphine yang berefek pada rasa nyaman dan rileks pada ibu sehingga terjadi peningkatan produksi ASI. Tujuan penelitian ini untuk mengetahui efek kombinasi back massage dan acupoint massage terhadap peningkatan kadar prolaktin. Jenis penelitan ini bersifat eksperimental epidemiologi dengan kelompok pembanding (post-test only with control group design). Penelitian ini dilaksanakan di BPM Meli Rosita selama 3 bulan. Sampel dalam penelitian ini adalah wanita post partum yang memenuhi kriteria inklusi dan ekslusi. Jumlah sampel 34 responden. Parameter keberhasilan adalah meningkatnya kadar prolaktin, data karakteristik sampel dan hasil pengukuran dinilai homogenitasnya dengan mengunakan Uji Kolmogorov-Smirnov. Analisis deskripsi untuk mengetahui rerata dan standar deviasi. Terjadi peningkatan yang signifikan nilai rerata prolaktin. Kombinasi Back massage dan Acupoint massage berefek terhadap peningkatan kadar prolaktin.
\end{abstract}

Corresponding Author:

Wita Asmalinda

Jurusan Kebidanan, Politeknik Kesehatan Kemenkes Palembang, Indonesia

Email: wita_asmalinda@yahoo.co.id

\section{PENDAHULUAN}

Waktu terbaik untuk keberlangsungan menyusui adalah dua puluh empat jam pertama setelah melahirkan. Pada jam-jam pertama setelah melahirkan bayi harus tetap disusui
(Rahayu, 2015). Kelancaran produksi dan aliran air susu ibu (ASI) sering dipengaruhi beberapa faktor seperti stres, kecemasan, kelelahan, dehidrasi dan nutrisi (Jogdeo and Bhore 2013). Stres berpengaruh pada pelepasan oksitosin dan prolaktin yang bertanggung jawab untuk refleks 
pengeluaran susu. Stres ibu menyebabkan blokade refleks let down yang akan berakibat bayi tidak puas menyusui (Rahayu, 2015) stres juga mempengaruhi bayi yang baru lahir lebih mungkin menjadi lemah dan terlalu mengantuk untuk menghisap dan menyusu dengan efektif (Khashanian, 2009 dalam Jogdeo dan Bhore 2013). Studi menunjukkan bahwa semakin banyak pemberian ASI pertama tertunda, semakin tinggi tingkat masalah (Jogdeo dan Bhore, 2013). ASI berguna untuk merangsang perkembangan sensorik dan kognitif, dan melindungi bayi terhadap penyakit menular dan kronis. Pemberian ASI eksklusif mengurangi kematian bayi karena penyakit anak-anak yang umum seperti diare atau pneumonia, dan membantu untuk pemulihan lebih cepat selama sakit. Menyusui berkontribusi pada kesehatan dan kesejahteraan ibu dengan mengurangi risiko kanker ovarium dan kanker payudara, meningkatkan kesehatan keluarga dan sebagai aset sumber daya nasional, dengan cara makan yang sehat dan aman bagi lingkungan (WHO, 2013).

Perangsangan puting susu karena isapan bayi yang bertujuan untuk mengaktivasi produksi prolaktin, maka bayi harus difiksasi secara benar, yaitu posisi yang benar antara lidah dengan gusi bayi terhadap papila dan areola mamae ibu, sebagai respon kelenjar hipofisis anterior akan meningkatkan sekresi hormon prolaktin, yang akan memacu pembentukan air susu yang lebih banyak (Apriani, 2017; Sherwood, 2018). Prolaktin adalah salah satu hormon dasar dalam sekresi air susu ibu dan peningkatannya mendorong pemberian ASI (Esfahani, et al., 2015).

Perangsangan puting susu dapat dilakukan dengan tindakan acupoint massage pada titiktitik akupresur di sekitar payudara. Back Massage pada titik meridian akan mengaktivasi pengeluaran hormon endorphine yang berefek pada rasa nyaman dan rileks pada ibu sehingga terjadi peningkatan produksi ASI (Lixin, W., 2008; Apriani, 2017; Rahayu, 2015; Parwati, et al., 2017). Terapi back massage yang diberikan pada awal-awal kelahiran saat bayi masih belajar mencari puting susu berefek pada peningkatan produksi kolostrum dan mempertahankan produksi air susu ibu, mengatasi kesulitan menyusui dan mencegah kelainan payudara selama proses menyusui (Juliastuti, 2018; Molassiotis, 2013; Patel, 2013).

Penelitian yang dilakukan dalam 10 tahun terakhir telah menunjukkan bahwa kadar hormon yang terkait dengan relaksasi dan stres secara signifikan diubah, yang mengarah ke regulasi suasana hati dan meningkatkan kesehatan jantung, ketika terapi pijat diperkenalkan pada perawatan prenatal perempuan. Pada wanita yang menerima pijatan dua mingguan hanya selama lima minggu, hormon seperti norepinefrin dan kortisol berkurang dan kadar dopamin dan serotonin meningkat (kadar hormon yang rendah dikaitkan dengan depresi). Perubahan kadar hormon ini juga menyebabkan lebih sedikit komplikasi selama kelahiran dan lebih sedikit kasus komplikasi yang baru lahir, seperti berat badan lahir rendah. Bukti menunjukkan kuatnya manfaat kesehatan ibu dan bayi baru lahir ketika pijatan terapeutik dimasukkan ke dalam perawatan prenatal rutin. Metode akupresur lebih efektif daripada metode lainnya dalam meningkatkan volume ASI. (Esfahani, et al., 2015).

Penelitian terkait uji manfaat kombinasi back massage dan acupoint massage terhadap peningkatan kadar prolaktin belum banyak, karenanya perlu dilakukan penelitian lanjutan tentang efektifitas kombinasi keduanya. Tujuan penelitian ini adalah untuk mengetahui efek back massage dan acupoint massage terhadap peningkatan kadar prolaktin pada ibu post partum. Manfaat penelitian adalah hasil penelitian ini dapat dipergunakan sebagai landasan ilmiah dan bahan referensi bagi petugas kesehatan (bidan) tentang manfaat back massage dan acupoint massage sebagai upaya alternatif pelayanan yang komprehensif pada ibu post partum yang menunjang keberhasilan ASI eksklusif.

\section{METODE}

Jenis penelitian ini bersifat eksperimental epidemiologi dengan kelompok pembanding (post-test only with control group design). Penelitian ini dilaksanakan di BPM Meli Rosita selama 3 bulan. Sampel dalam penelitian ini adalah ibu post partum yang memenuhi kriteria inklusi dan eksklusi. Jumlah sampel sebanyak 34 orang, Pengambilan sampel penelitian dilakukan secara proporsive sampling, klien yang ada pada waktu pngambilan sampel, yang memenuhi kriteria insklusi dan ekslusi diambil menjadi sampel. Untuk menentukan sampel masuk dalam kelompok perlakuan atau kelompok kontrol adalah dengan cara diundi (lotre), Sampel yang mendapatkan angka 1 dimasukkan dalam kelompok perlakuan dan sampel yang mendapatkan angka 2 dimasukkan dalam kelompok kontrol. Kepada semua sampel dijelaskan tujuan, prosedur, manfaat dan risiko 
sebagai sampel dalam penelitian ini. Setelah mendapatkan persetujuan sampel kemudian menandatangani informed concent menjadi responden dalam penelitian ini. Variabel penelitian ini adalah variabel bebas (independen) back massage dan acupoint massage dan variabel terikat (dependen) kadar prolaktin. Pengambilan darah vena dan pemeriksaan prolaktin dilakukan oleh petugas kesehatan dari Balai Besar Laboratorium Kesehatan (BBLK) Daerah Sumatera Selatan. Terapi back massage dan acupoint massage dilakukan oleh terapis Klinik Hombc yang terlatih dan telah tersertifikasi. Peralatan dan bahan yang digunakan untuk back massage dan acupoint massage antara lain; postnatal oil, kain sarung, selimut, bantal 3 buah, handuk, kursi. Tidak ada persiapan khusus dalam melakukan terapi back massage dan acupoint massage. Langkah pertama melakukan back massage mengunakan gerakan effleurage pada punggung ibu dari belakang dengan gerakan sirkuler 6 kali. selanjutnya massage gerakan friction mulai dari tulang sacrum ke arah atas menyusuri sisi kanan dan kiri tulang belakang sebanyak 6 kali, lakukan massage gerakan chisel fist, lakukan massage gerakan petrisage pada GB21 sebanyak 6 kali, lakukan acupoint effleurage pada pangkal payudara dari belakang ibu dengan gerakan sirkuler sebanyak 6 kali, kemudian lakukan massage gerakan petrisage secara sirkuler pada sekitar pangkal payudara sebanyak 6 kali, lakukan massage gerakan effleurage arah luar dari areola mengikuti arah jarum jam 9 dan 3, diikuti dengan pijatan efflurage yang sama namun pada arah jam 12 dan jam 6. Masingmasing pijatan sebanyak 6 kali, lakukan massage gerakan efflurage pada bagian bawah tulang klavikula kanan dan kiri, dilanjutkan pada jari dibawahnya, yaitu pada permulaan payudara, kemudian menyusuri tulang sternum kearah bawah, lakukan massage pada titik acupuncture ST13, ST16, pada dada kanan dan kiri dilanjutkan dengan pijatan berirama stakatoto pada masing-masing titik, lakukan massage gerakan friction memutar pada bagian bawah tulang kanan dan kiri dilanjutkan pada 4 jari dibawahnya, yaitu pada permulaan payudara (Widyawati, 2017; Lee, M. 2004).

Penelitian ini telah mendapatkan rekomendasi persetujuan etik dari Komisi Etik Penelitian Politeknik Kesehatan Makasar No. 1041/KEPK-PTKMKS/VIII/2019.

\section{HASIL}

Tabel 1. Karakteristik UsiaResponden

\begin{tabular}{lrl}
\hline \multicolumn{1}{c}{ Usia (tahun) } & \multicolumn{1}{c}{ n } & \% \\
\hline Produktif (20-35) & 28 & 82,4 \\
Risiko (>36 ) & 6 & 17,6 \\
\hline
\end{tabular}

Dari tabel 1 menunjukkan usia responden terbanyak adalah usia produktif sebesar 28 orang $(82,4 \%)$

Tabel 2. Karakteristik Gravida Responden

\begin{tabular}{ccc}
\hline Gravida & n & \% \\
\hline Primigravida & 20 & 58,8 \\
Multigravida & 14 & 41,2 \\
\hline
\end{tabular}

Dari tabel 2 menunjukkan gravida responden terbanyak adalah primigravida sebesar 20 orang $(58,8 \%)$

Tabel 3. Perbedaan Nilai Rerata Prolaktin Kelompok Perlakuan Back Massage dan Accupoin Massage dengan Kelompok Kontrol (Independent samples t-test)

\begin{tabular}{lcccc}
\hline Variabel & n & Rerata \pm SD & $\begin{array}{c}\text { Min- } \\
\text { Maks }\end{array}$ & $\begin{array}{c}p- \\
\text { value }\end{array}$ \\
\hline Prolaktin & 17 & $515,08 \pm 154,51$ & $255,86-$ & 0,000 \\
post 1 & & & 835,70 & \\
$(\mathrm{ng} / \mathrm{ml})$ & & & & \\
Prolaktin & 17 & $177,43 \pm 114,928$ & $102,39-$ & \\
post 2 & & & 536,03 & \\
$(\mathrm{ng} / \mathrm{ml})$ & & & & \\
\hline
\end{tabular}

Dari tabel 3 menunjukkan nilai rerata prolaktin post kelompok perlakuan back massage dan acupoint massage adalah 515,08 $\pm 154,51$, sedangkan nilai rerata prolaktin post kelompok kontrol adalah sebesar 177,43 $\pm 114,928$ dengan selisih rerata adalah sebesar 337,65 . Hasil uji statistik mengunakan uji Independent t-test didapatkan nilai $p$-value $=0,000$ dengan nilai $\alpha=0,05 \quad(p$-value $<\alpha)$. Ho ditolak, hal ini menunjukkan ada perbedaan yang bermakna nilai rerata prolaktin post pada kelompok perlakuan back massage dan acupoint massage dengan kelompok kontrol.

\section{PEMBAHASAN}

Dari hasil statistik terhadap kadar prolaktin pada kelompok perlakuan back massage dan acupoint massage mengalami peningkatan yang bermakna. Hasil penelitian Esfahani, et al (2015) menunjukkan akupresur (acupoint massage) berpengaruh terhadap volume ASI pada 2 dan 4 minggu setelah intervensi. 
Ada dua hormon yang secara langsung mempengaruhi proses menyusui yaitu hormon prolaktin dan oksitosin. Sejumlah hormon lain, seperti estrogen, terlibat secara tidak langsung dalam laktasi (Lawrence RA, 2011). Kadar prolaktin dalam darah pada saat hamil normal $10-25 \mathrm{ng} / \mathrm{mL}$ terus meningkat sampai 200$400 \mathrm{ng} / \mathrm{mL}$ pada akhir kehamilan dan akan terus meningkat tajam pada permulaan menyusui hingga terjadi hiperprolactinemia (Sferoff, 2010; Guyton and Hall, 2012). Pada akhir kehamilan, hormon prolaktin berperan untuk pembentukan kolostrum. Plasenta mensekresi sejumlah besar human chorionic somatomammotropin, yang mempunyai sifat laktogenik, untuk menyokong prolaktin dari hipofisis ibu selama hamil. Karena efek supresi dari estrogen dan progesteron, hanya beberapa milimeter cairan saja yang disekresi setiap harinya. Segera setelah bayi lahir sekresi estrogen dan progesteron hilang, memungkinkan efek laktogenik prolaktin dari kelenjar hipofisis ibu yang mengambil peran air susu. Sekresi air susu memerlukan sekresi pendahuluan yang adekuat dari hormon pertumbuhan, kortisol, paratiroid dan insulin. Hormon-hormon ini diperlukan untuk menyediakan asam amino, asam lemak, glukosa, dan kalsium yang dibutuhkan untuk pembentukan air susu (Guyton and Hall, 2012; Ganong, 2014). Kadar prolaktin yang paling tinggi adalah pada saat malam hari, dengan menyusui pada malam hari akan mengaktivasi kelenjar hipofisis untuk merilis simpanan hormon prolaktin untuk merangsang produksi ASI (Guyton and Hall, 2012; Ganong, 2014; Sherwood, L., 2018). Sekresi air susu dimulai pada hari kedua dan ketiga, dimana kadar hormon estrogen dan progesteron yang menghambat pengeluaran prolaktin menurun (Guyton and Hall, 2012).

Ketika bayi menyusui, merangsang puting susu akan mengaktivasi ujung-ujung saraf sensorik yang mempunyai fungsi reseptor mekanik. Rangsangan ini akan diteruskan ke hypothalamus melalui medulla spinalis, sehingga hypothalamus akan menekan faktor-faktor penghambat pengeluaran prolaktin yang disebut hormon penghambat prolaktin. Hormon ini sama dengan dopamin katekolamin yang dapat menurunkan sekresi prolaktin sebanyak 10 kali lipat, dan sebaliknya akan merangsang faktorfaktor yang memacu produksi prolaktin sehingga kadar prolaktin dalam darah meningkat, dan merangsang produksi susu oleh alveoli (Guyton and Hall, 2012). Kadar prolaktin paling tinggi sekitar 30 menit setelah permulaan periode menyusui, jadi efek yang paling penting adalah membuat susu untuk periode berikutnya. Selama beberapa minggu pertama, semakin banyak bayi menyusu dan menstimulasi puting, semakin banyak prolaktin yang diproduksi dan semakin banyak ASI diproduksi. Efek ini sangat penting pada saat laktasi menjadi mapan. Meskipun prolaktin masih diperlukan untuk produksi ASI, setelah beberapa minggu tidak ada hubungan yang erat antara jumlah prolaktin dan jumlah susu yang dihasilkan. Namun, jika ibu berhenti menyusui, sekresi ASI dapat berhenti juga, maka air susu akan mengering (Bolman, et al., 2013).

Sekresi prolaktin meningkat jika kelenjar diangkat dari sel tursika atau jika tangkai kelenjar hipofisis diangkat seluruhnya. Hal ini tampak bahwa PRL berada di bawah penghambatan terus menerus (tonik) oleh hormon penghambat pelepasan prolaktin (Prolactin-release inhibiting hormone PRIH) yang sebenarnya mungkin dopamin. Sel-sel hipofisis mempunyai reseptor dopamin yang mengurangi pelepasan PRL dan menghambat transkripsi sel dopamin, melalui penurunan kadar cAMP, levodopa dan prekursor dopamin yang menghambat pelepasan PRL ketika merangsang pelepasan GH. Adanya faktor pelepasan positif (Prolactin realising hormone; PRH) belum dipastikan dengan baik. Molekul yang menyerupai fragmen oksitosin melepaskan PRL, rangsangan-rangsangan yang menyebabkan pelepasan oksitosin juga melepaskan PRL. Estrogen merangsang pelepasan prolaktin, dengan mengurangi reseptor dopamin dalam hipofisis dan estrogen juga merangsang transkripsi gen PRL. Kadar prolaktin meningkat dalam kehamilan lanjut dan laktasi (Guyton and Hall, 2012; Ganong, 2014; Lawrence, 2011).

Akupresur adalah jenis obat tradisional Cina yang didasarkan pada tekanan pada titik akupuntur tertentu di dalam tubuh yang mengarah pada keseimbangan energi dalam tubuh (Bolman, et al., 2013). Stimulasi akupresur back massage, adalah aplikasi tekan dengan ibu jari dan ujung jari ke titik pada tubuh untuk efek terapi dalam bentuk pijat punggung. Acupoint massage adalah teknik relaksasi, dan mengurangi stres yang bertanggungjawab atas peningkatan produksi susu (Patel, 2013). Acupoint massage pada titik-titik auricular efektif pada produksi air susu ibu yaitu pada titik AH10, CO18, CO13, CO12, dan CO4 (Zhou et al, 2009; Esfahani, et al., 2015; Lee, 2004; Widyawati, 2017). Akupresur yang umum digunakan dalam bidang kebidanan mengunakan tangan untuk menekan beberapa titik akupunktur pada tubuh. Akupresur dapat memulihkan dan mengimbangi energi tubuh untuk meningkatkan fungsi tubuh (Mollart 
and Leiser, 2013; Gao, 2012; Akbarzadeh, 2014)

Back massage dan Acupoint massage adalah tindakan yang dapat membantu memaksimalkan prolaktin dan reseptor oksitosin dan meminimalkan efek samping terlambat menyusui oleh bayi. Back massage dan acupoint massage dapat memulihkan dan menyimbangkan energi tubuh untuk meningkatkan fungsi tubuh. Back massage dan acupoint massage mampu menstimulasi pelepasan endorpin, memblokir reseptor rasa sakit dan melepaskan pelepasan toksin (Mollart and Leiser, 2013; Witzel, T., 2011), juga dapat mempengaruhi produksi prolaktin untuk meningkatkan produksi ASI (Raras, et al., 2016; Arumsari, et al., 2018; AlNuaimi, 2017; Rizk, S.A., 2013). Acupoint massage untuk laktasi melalui titik meridian menurut organ yang akan ditangani (Rahayu, 2015 dalam Parwati, et al., 2017; Arumsari, et al., 2018; Al-Nuaimi, 2017). Acupoint massage sangat efektif sehingga sangat pantas untuk dicoba jika ibu mengalami masalah laktasi. Terapi dilakukan dengan tekanan kuat pada titik

\section{DAFTAR PUSTAKA}

Akbarzadeh, M., Masoudi, Z., Hadianfard, M. J., Kasraeian, M., \& Zare, N. (2014). Comparison of the effects of maternal supportive care and acupressure (BL32 acupoint) on pregnant women's pain intensity and delivery outcome. Journal of pregnancy, 2014.

Al-Nuaimi, N., Katende, G., and Arulappan, J. (2017). Breastfeeding Trends and Determinants: Implications and recommendations for Gulf Cooperation Council countries. Sultan Qaboos University Medical Journal, 17(2), 155161.

Apriani, D. (2017). Pengaruh Metode Pijat Endhorpin Terhadap Tingkat Kecemasan Ibu Nifas di Wilayah Kerja Pyskesma Gunung Sari. Jurnal Kedokteran Yarsi 25(3), 163-171.

Arumsari, D. R., Indrawan, I. W. A., \& Wahyuni, E. S. (2018). The Combination of Acupressure and Affirmation Relaxation as an Alternative Method to Increase Breast Milk Production and Breastfeeding Selfefficacy. Research Journal of Life Science, 5(1), 66-76.

Bolman, M., Saju, L., Oganesyan, K., Kondrashova, T., dan Witt, A. M. (2013). Recapturing the Art of Therapeutic Breast
GB21 yang merupakan poin bagus untuk membantu refleks letdown. REN 17 bersama dengan memijat payudara ke arah puting sementara memberi makan adalah sesuatu yang dapat dilakukan pada diri sendiri dan dapat membantu sirkulasi dalam payudara. SI1 adalah titik lain yang bisa di coba sendiri oleh ibu yang sangat efektif dalam membantu aliran ASI (Widyawati, 2017; Zick, 2012).

\section{SIMPULAN}

Berdasarkan hasil analisis pembahasan, maka dapat disimpulkan bahwa, terjadi peningkatan yang signifikan nilai rerata prokatin setelah 24 jam dilakukan terapi back massage dan acupoint massage dengan nilai p-value 0,0001, Hasil uji Independent t-test nilai rerata prolaktin post kelompok perlakuan dan kontrol didapatkan nilai selisih rerata kedua kelompok adalah sebesar 337.65 dengan nilai $p$-value $=0,0001$. Disarankan untuk dilakukan penelitian lebih lanjut terhadap parameter oksitosin.

Massage during Breastfeeding. Journal of Human Lactation, 29(3), 328-331.

Esfahani, M. S., Berenji-Sooghe, S., Valiani, M., and Ehsanpour, S. et al (2015). Effect of acupressure on milk volume of breastfeeding mothers referring to selected health care centers in Tehran. Iranian Journal of Nursing and Midwifery Research, 20(1), 7-11.

Gao, S.B., Wu, H., and Gao, C.-S. (2012). Effects of Guoshu acupoint pressure therapy on acute mastitis during lactation. Zhongguo Zhen Jiu = Journal Chinese Acupuncture dan Moxibustion, 32(9).

Ganong. WF. (2014). Fisiologi Kedokteran. Edisi ke-23. Jakarta: EGC.

Guyton and Hall. (2012). Text Book of Physiology Medicine (Eds.11 $\left.1^{\text {th }}\right)$. Jakarta: EGC.

Jogdeo, B. A., \& Bhore, D. N. R. (2016). The Effect of Back Massage on Let Down Reflex among Mothers Who Had Undergone Cesarean Section. International Journal of Science and Research (IJSR), 5(3).

Juliastuti, Sulastri. (2018). Pengaruh Pemberian Massage Depan (Breast Care) dan Massage Belakang (Pijat Oksitosin) Terhadap Produksi ASI Ibu Post Partum di 
Rumah Sakit Zainal Abidin Banda Aceh. Jurnal Ilmiah PANNMED, 2(3), 227-231.

Lawrence RA, L. R. (2011). Breastfeeding: a guide for the medical profession (6th Editio). London: Mosby, an imprint of Elsevier Inc.

Lee, M. K., Chang, S. B., dan Kang, D.-H. (2004). Effects of SP6 Acupressure on Labor Pain and Length of Delivery Time in Women During Labor. The Journal of Alternative and Complementary Medicine, 10(6), 959-965.

Lixin, W., Hongcai, W., Ying, H., and Caifen, L. et al (2008). Clinical Observation on the Effects of Electroacupuncture at Shaoze (SI 1) in 46 Cases of Postpartum Postpartum. Journal of Traditional Chinese Medicine (28). http://www.journaltcm.com/modules/Journ al/contents/stories/083/2.pdf

Molassiotis, A., Russell, W., Hughes, J., Breckons, M., Lloyd-Williams, M., Richardson, J.,Ryder, W. et al (2013). The effectiveness and cost-effectiveness of acupressure for the control and management of chemotherapy-related acute and delayed nausea: Assessment of Nausea in Chemotherapy Research (ANCHoR), a randomised controlled trial. Health Technology Assessment (Winchester, England), 17(26), 1-114. https://doi.org/10.3310/hta17260

Mollart, L., \& Leiser, B. (2013). Acupressure for the perinatal period. Women and Birth, 26, S43.

Parwati, D. M. W., Hartati, L. E., dan Suheri, T. (2017). The Effect of Breast Acupressure and Oxylosins Massage to Improve the Breast Milk Production in Postpartum Mother. Journal JMSCR 5(10), 2875628760.

Patel, U., \& Gedam, D. S. (2013). Effect of back massage on lactation among postnatal mothers. International journal of medical research and Review, 1(01).

Rahayu, D., Santoso, B., dan Yunitasari, E. 2015. Produksi ASI dengan Intervensi Acupresure Point For Lactation dan Pijat Oksitoksin. Jurnal Ners, 10(1), 9-19.
Raras, N. S., Suwondo, A., Wahyuni, S., \& Laska, Y. (2016). Different Amount of Prolactin Hormone Before and After Acupressure-aromatherapy Combination Technique in Lactation: Epidemiologicalclinic Study on Post Partum Mother in Surakarta District Hospital. In ASEAN/Asian Academic Society International Conference Proceeding Series.

Rizk, S. A. (2013). Effect of acupressure on menopausal symptoms among women. $J$ American Sci, 9, 416-24.

Sferoff, L., Fritz, M.A. (2010). Neuroendocrinology in Clinical Gynecology Endocrinology and Infertility. (Eds. 10th). Lippincot William \& Wilkins.

Sherwood, L. (2018). Fisiologi Manusia dari Sel Ke Sistem. Edisi 8. Jakarta: EGC.

WHO. (2013). Infant and young child feeding Model Chapter for textbooks for medical students and allied health professionals. Geneva. Retrieved from https://www.ncbi.nlm.nih.gov/books/NBK 148965/pdf/

Widyawati, MN., Suprihatin, K dan MN, Sutarmi. (2017). Loving Postnatal Treatment. Semarang: IHCA.

Witzel, T., Napadow, V., Kettner, N. W., Vangel, M. G., Hämäläinen, M. S., and Dhond, R. $\mathrm{P}$ et al (2011). Differences in cortical response to acupressure and electroacupuncture stimuli. $B M C$ Neuroscience, 12, 73.

Zhou, H., Li, L., Li, D., Li, X., Meng, H., Gao, X., and Zhu, Y.et al (2009). Clinical observation on the treatment of postcesarean hypogalactia by auricular points sticking-pressing. Chinese Journal of Integrative Medicine, 15(2), 117-120.

Zick, Suzanna Maria, Wyatt, G. K., Murphy, S. L., Arnedt, J. T., Sen, A., dan Harris, R. E et al (2012). Acupressure for persistent cancer-related fatigue in breast cancer survivors (AcuCrft): a study protocol for a randomized controlled trial. $B M C$ Complementary and Alternative Medicine, 12, 132 . 